УДК 8.1: 81.34: 81.35

DOI: $10.24144 / 2617-3921.2019 .17 .33-40$

Еріка Есенова старший викладач кафедри теорії та практики перекладу ДВНЗ «Ужсгородський національний університет» orcid.org/0000 000238433296 м. Ужгород, Украӥна, +380990069 130, brightsunshine_068@yahoo.com

\title{
Етапи асиміляції запозичених слів у мові-реципіснті: теоретичні аспекти проблеми
}

Анотація. Стаття присвячена проблематиці засвоєння слів іншомовного походження лексичною системою мови-реципієнта. Метою статті $\epsilon$ подання огляду лінгвістичної літератури, що пов'язана $з$ дослідженням особливостей асимілячії запозичених лексем. Актуальність даної проблематики полягає в тому, що для сучасних мов невиріменою залишається проблема нормалізації та адаптації запозичень у мовіреципієнті. Відсутність чітких та уніфікованих норм щодо передачі матеріальної форми запозичених апелятивів призводить до зростання варіативності передачі нових лексем з різних мов. Особливо актуальним ие є сьогодні, коли украӥнська мова вступає у прямі, безпосередні контакти з багатьма мовами світу.

Ключові слова: мовні контакти, іншомовне слово, процес запозичення, адаптація, фонетичне засвоєння, укорінення, прототип.

Abstract. The studying of language contacts in linguistics is considered to be very significant and interesting. The process of borrowing lexical units from one language into another cannot be prevented, as there are hardly any isolated nations and peoples in the world. The main reason for it is the globalization of all spheres of human activity. Lexical borrowing is a very complicated process, the 
result of which is the transformation of the word of the source language into a new lexical unit of the target language in accordance with its phonetical and grammatical peculiarities. Loan words enter the system of the recipient-language and in the course of time become assimilated in this language. The given article is devoted to some theoretical problems of assimilation of borrowed lexical units in the target language. Linguists distinguish different stages of entering of a borrowed lexical unit into the system of the target language. In the present article we will make an attempt to analyze points of view of different linguists on this complex language phenomenon. We will focus mainly on the stages of assimilation of loan-words.

Keywords: language contacts, borrowing, loan-word, phonetical assimilation, prototype, source language, target language.

Вступ. Проблематика мовних контактів вважається однією 3 найскладніших і водночас найцікавіших у сучасному мовознавстві. Не існує мов, в яких не було б запозичених слів, оскільки не існує народів, які протягом свого історичного розвитку не мали б зв'язків з іншими народами. Взаємодія різних мовних систем, що безпосередньо пов'язана з історією та культурою народів, найяскравіше розкривається при вивченні мовних елементів, які стали спільними для двох або кількох мов. Виникають нові реалії i, як наслідок, нові одиниці мови, що їх позначають. У процесі міжнародних зв'язків відбувається поповнення лексичного складу різних мов. Коли запозичені слова відповідають суспільній потребі у вираженні того чи іншого поняття, вони входять у лексичний склад мови-реципієнта, асимілюються в ній і стають їі надбанням.

Останніми десятиліттями спостерігається стрімкий розвиток різних галузей науки та техніки. Прискорення соціального розвитку країн світу зумовлює зростання обсягу міжнародної інформації. У зв’язку з цим простежується значне збільшення кількості запозичень у національних мовах, які є своєрідними віхами в історії мови, що відображають значні наукові, економічні, історичні та культурні події у житті народів. Українська мова теж постійно взаємодіє з іншими мовами світу, збагачується тим новим та прогресивним, що відбувається у науці, техніці, суспільному житті. Мова $є$ основою взаєморозуміння між народами, i саме 3 цього випливає зацікавленість у вивченні історії засвоєння іншомовних слів у чужому мовному середовищі.

Питання вивчення запозиченої лексики, такі як види та ступені іiі асиміляції, входження іншомовного слова до лексичного складу тієї чи іншої мови, функціонування запозиченої лексики у складі мови-реципієнта $\epsilon$, на думку багатьох дослідників, «вічними» проблемами мовознавства, що привертають увагу лінгвістів та викликають значний інтерес з боку носіїв мови, які не мають безпосереднього відношення до мовознавства. 
Метою даної статті $є$ подання короткого огляду лінгвістичної літератури, пов'язаної 3 дослідженням процесу асиміляції іншомовних лексичних одиниць у системі мови-реципієнта. Ми зробимо спробу проаналізувати точки зору різних мовознавців на цю проблему. Особливу увагу звернемо на ключові етапи проникнення чужомовної лексичної одиниці у нове мовне середовище.

Методологія та методи дослідження. Методи та процедури дослідження визначаються метою, завданнями та матеріалом, що аналізується. Вони включають як загальнонаукові методи, так i ті, що входять до різних парадигм власне лінгвістичного дослідження. Для вирішення поставлених завдань використовуються зокрема описовий та порівняльно-зіставний метод, оскільки ми маємо справу 3 порівнянням мовних одиниць типологічно неспоріднених мов. Методологія дослідження базується на вивченні мови як цілісної динамічної системи та багатогранного явища. Застосовуються також загальнонаукові методи, такі як індукція, дедукція, аналіз, синтез тощо.

Виклад основного матеріалу дослідження. Лексичне запозичення це дуже складний процес, суттю якого є перетворення іншомовного слова згідно з фонетичними та граматичними законами мови-реципієнта. Процес адаптації (асиміляції) закінчується появою нового для мови-реципієнта слова, i тому запозичення $є$ одним із засобів збагачення словника. 3 часом деякі запозичені слова, які позначають життєво необхідні, суспільно важливі, загальновідомі поняття, включаються у лексичний склад мови й існують у ньому поряд 3 питомими словами, і їхнє чужомовне походження поступово забувається. При цьому, за влучним зауваженням В.І. Комлєва, кожне запозичене слово «має потенційну можливість повністю асимілюватися і втратити вигляд іншомовного слова» [11, с. 14].

Суттю запозичення деякі дослідники вважають саме ті зміни, які відбуваються у звуковому складі, морфологічній та словотворчій будові слова. А характер цього процесу залежить від походження іншомовного матеріалу, його структури, значення, сфери вживання, часу запозичення i способу проникнення.

Важливою є адаптація чи пристосування іншомовного матеріалу до системи мови-реципієнта, тому що воно передбачає розв'язання питань графічного та орфографічного порядку. На думку А.О. Білецького, у широкому розумінні «адаптація означає асиміляцію іншомовного лексичного матеріалу на фонологічному і семантичному рівнях, а у вужчому розумінні - власне на граматичному рівні» [3, с. 17]. Важливим показником асиміляції $\epsilon$ словотворча активність, тобто здатність іншомовних слів утворювати нові слова у мові-реципієнті.

М.С. Коробова асиміляцію визначає як «засвоєння мовою слова, що запозичується, яке відбувається у напрямку максимального наближення його фонетичних, графічних, граматичних та лексико-семантичних характеристик 
до відповідних норм мови-реципієнта» $[12$, с. 100]. I.М. Крейн під асиміляцією розуміє ступінь наближеності запозичення до властивостей лексики мови-реципієнта; тут же підкреслюється, що «на основі опису цих властивостей створюється їх система (що називається критеріями), відповідність або невідповідність якій визначає ступінь асиміляції запозичення» $[14$, с. 47$]$. У наукових працях зустрічаються різні назви для запозичень залежно від ступеня їх адаптації: засвоєні слова, незасвоєні слова, варваризми, екзотизми, запозичені слова, іншомовні слова.

Мовознавці, як правило, виділяють декілька етапів засвоєння іншомовного слова. В.М. Аристова розрізнює три етапи:

1. Етап проникнення - коли слова співвідносяться лише 3 особливостями дійсності країни мови-джерела. На цьому етапі вони можуть зберігати своє іншомовне написання, а у разі фонетико-графічного оформлення засобами мови-реципієнта вони характеризуються фонетико-орфографічною варіативністю.

2. Етап запозичення - коли слово поширюється у мові реципієнті i співвідноситься 3 дійсністю країни цієї мови, хоча семантичні зв'язки 3 мовою-джерелом ще дуже сильні.

3. Етап укорінення - коли слово повністю підпорядковується нормам мовиреципієнта, використовуючи можливості внутрішньої еволюції (словотвір, абревіація, семантичні та стилістичні зміни) [2, с. 8-10].

При цьому дослідниця зауважує, що членування запозичень за ступенем адаптації буде правомірним лише в будь-який певний історичний момент, тобто при синхронному підході до лексики мови. Для кожного наступного періоду така класифікація буде анахронічною відносно до лексичної системи мови, яка постійно розвивається. Засвоєння мовою запозичених слів - складний діахронічний процес, в якому переплітаються зв'язки і відношення, з одного боку, мови-реципієнта і мови-джерела, а 3 другого боку, - в системі мови-реципієнта. Еволюція запозичених слів може бути наочною лише при вивченні їх в історичному плані з урахуванням факторів лінгвістичного та екстралінгвістичного характеру [2, с. 8].

Л.Н. Сорокіна також виділяє декілька стадій засвоєння іншомовного слова мовою-реципієнтом:

1) Уведення іншомовної одиниці у мову-реципієнт, коли якості мови-джерела відчуваються сильніше, ніж норми мови-реципієнта.

2) Асиміляція, тобто пристосування слова до системи мови-реципієнта і входження в неї, коли відбувається втрата певних якостей іншомовності і набуття якостей системи, що запозичила слово.

3) Функціонування слова, яке проявляється у засвоєнні його мовоюреципієнтом, коли слово стає повноправним членом системи, що його запозичила [19, с. 101].

Л.П. Крисін виділяє п'ять етапів засвоєння іншомовного слова, при цьому останнім (завершальним) етапом він вважає реєстрацію іншомовного 
слова у тлумачному словнику, оскільки цей факт указує на його належність до лексико-семантичної системи мови-реципієнта [15, с. 77]. Я.А. Голдованський вважає, що на шляху до повного лексичного засвоєння запозичене слово неминуче проходить три етапи: а) етап інновацій, тобто первинного вживання у мові-реципієнті; б) етап віртуалізму, коли слово розповсюджується серед меншості населення; в) етап неологізму, коли словом користується більшість населення [4, с. 145].

Запозичена лексика, на думку І.В. Муромцева, проходячи в результаті міжмовного контактування етапи входження, засвоєння й укорінення, зазнає впливу внутрішніх закономірностей розвитку мови-рецептора. Цей вплив поряд 3 дією інших чинників може призводити або до появи у мові-рецепторі нових, або до дальшого розвитку вже існуючих закономірностей на різних мовних рівнях (на фонетичному також) [16, с. 72-73].

Р. Філіпович виділяє два періоди засвоєння іншомовних слів:

1. Етап, що триває від моменту, коли слово проникає у мову-реципієнт, до того, як воно інтегрується у систему цієї мови.

2. Етап, що починається з інтеграції слова у нову мовну систему, коли воно починає поводитися як будь-яке інше слово мови-реципієнта і підлягає процесам адаптації, що є типовими для цієї мови.

При цьому усі зміни, що зафіксовані протягом першого періоду, мовознавець називає первинними змінами, а сам процес - первинною адаптацією. Зміни, що відбуваються у другому періоді, називаються вторинними змінами, а процес - вторинною адаптацією. Дослідник також зауважує, що у кожному з цих періодів відбуваються зміни на усіх рівнях: фонологічному, морфологічному, семантичному [22, с. 118].

Г. Пауль так само звертає увагу на те, що «зміни, яким підлягають іншомовні слова при запозиченні, слід відрізняти від тих змін, яких вони зазнають після того, як закріпились у мові» [17, с. 465]. Але оскільки багато слів дійшли до нас у формі, яку вони отримали через довгий час після їх запозичення, розмежувати ці зміни буває дуже важко, і цілком зрозуміло, що запозичені слова зазнають багатьох змін, так само як і питомі слова.

Ю.О. Жлуктенко вважає, що запозичення лексичних одиниць - лише один 3 етапів загального процесу. При цьому початковою стадією $\epsilon$ використання лексичної одиниці в контекстах іншої мови. I тільки наступним етапом є запозичення лексичної одиниці, тобто сприйняття іiі іншою мовною системою як постійного елемента. Запозичення, на думку мовознавця, відбувається тільки після регулярного використання нової одиниці багатьма членами спільноти, коли включення іiі в іншу систему необхідність. Третім етапом дослідник називає інтеграцію, тобто глибоке засвоєння іншомовної одиниці, коли мовці перестають відчувати іiі іншомовний характер [6, с. 133].

Т.Г. Амірова вважає, що чим частіше слово зустрічається у мовіреципієнті, тим швидше i повніше воно асимілюється в ній. Ознакою 
засвоєності запозичень дослідниця вважає асиміляцію слова на усіх рівнях: а) фонетичну асиміляцію; б) граматичну асиміляцію; в) регулярну вживаність у мові; г) семантичну асиміляцію (зустрічається не завжди) [1, с. 10]. Повністю асимільованим дослідниця вважає таке слово, яке фонетично, орфографічно, граматично i семантично змінилось у відповідності із законами мови-реципієнта. Якщо ж слово не зазнає хоча б однієї з цих змін, його слід відносити до частково або відносно асимільованих слів. Слова ж, які не зазнали жодних змін, слід виділяти, на відміну від запозичень, у розряд іншомовних вкраплень.

Однак О.Б. Шахрай зауважує, що навіть у рамках одного з цих аспектів оформлення іншомовних слів поняття засвоєності та незасвоєності є вельми відносним. Особливо це стосується фонетичного аспекту, де асиміляція має різноманітні форми через різницю у фонетиці мови-джерела та мовиреципієнта $[20$, с. 55]. Серед додаткових факторів, які впливають на асиміляцію слів у мові-реципієнті, О.І. Дмитровська називає такі: а) тривалість перебування слова у мові; б) спорідненість мов; в) наявність моделей засвоєння; г) розповсюдженість знання мови-джерела [5, с. 24-29].

Термін запозичення, на думку Л.П. Кислюк, є родовим поняттям стосовно термінів іншомовне слово та засвоєне слово, які перебувають на тому чи іншому ступені адаптації до мови-реципієнта. При цьому іншомовними вважаються запозичені слова, оформлені за зразком чужої мови (транслітерований запис, невідмінюваність). Ті 3 них, які проходять шлях пристосування до мови-реципієнта, змінюючи звукове оформлення, стаючи відмінюваними внаслідок появи флексій, виявляючи словотвірну активність і навіть утворюючи нові лексико-семантичні варіанти, стають повністю засвоєними мовою [7, с. 4]. Ступінь же засвоєння слова залежить від часу проникнення, належності до загальновживаної чи спеціальної лексики, наявності соціального замовлення, потреби в слові, особливостей семантики.

Загалом, традиційно розрізнюють три типи формальної асиміляції (адаптації) запозичених слів: фонетичну, орфографічну й граматичну (морфологічну). Між першим і другим типами існує тісний зв'язок, тому, за словами Ю.Г. Коротких, часто говорять про фонографічні особливості засвоєння. Усі три типи взаємодіють одне з одним, що зумовлено системним характером словникового складу [13, с.9]. Види асиміляції запозичень у мові-реципієнті на матеріалі різних мов та методики 价 дослідження розглядалися багатьма мовознавцями (див. Г.Ю. Князева [8], Т.П. Ковмир [9], К.О. Комарова [10], И.Б. Свечина [18], Т.А. Штирбу [21]).

Висновки 3 дослідження та перспективи подальших розвідок. Як бачимо, думки мовознавців, які досліджували проблеми асиміляції іншомовних одиниць у мові-реципієнті, різняться. Проаналізувавши наукові роботи по даній проблематиці, можемо зробити наступні висновки та узагальнення: 
1. Запозичення лексичних одиниць - це надзвичайно складний та тривалий процес, сутністю якого $є$ трансформація іншомовного слова згідно з фонетичними та граматичними правилами мовиреципієнта.

2. Результатом цього процесу $є$ поява у мові-реципієнті нової лексичної одиниці, яка може мати різний ступінь засвоєння.

3. Основними етапами засвоєння іншомовного слова у мові-реципієнті можемо вважати наступні: етап проникнення, етап запозичення та етап укорінення лексичної одиниці.

4. Ознакою повної асиміляції запозиченої лексеми є іiі засвоєння на усіх рівнях: фонетичному, графічному, граматичному, словотвірному та семантичному.

\section{ЛIТЕРАТУРА}

1. Амирова Т.Г. Заимствование и его роль в развитии и обогащении синонимии: автореф. дисс. ... канд. филол. наук: 10.02.15. Баку, 1975. $12 \mathrm{c}$.

2. Аристова В. М. Англо-русские языковые контакты (Англизмы в русском языке). Ленинград, 1978. 151с.

3. Білецький А.О. Адаптація давньогрецького ономастикону в східнослов' янських мовах. Іноземна філологія. 1971. Вип. 24. С. 17-23.

4. Голдованский Я.А. Проблемы этимологической идентификации лексических заимствований (на материале англицизмов в украинском языке): дисс. ... канд. филол. наук: 10.02.15. Ужгород, 1987. 195с.

5. Дмитровская Е.И. Фоно-орфографическое, морфологическое и лексико-семантическое освоение англицизмов современным немецким языком: дисс. ... канд. филол. наук: 10.02.04. Львов, 1969. $345 \mathrm{c}$.

6. Жлуктенко Ю.А. Лингвистические аспекты двуязычия. Киев, 1974. 176с.

7. Кислюк Л.П. Словотвірний потенціал запозичень в сучасній українській літературній мові (на матеріалі англійських та німецьких запозичень): автореф. дис. ... канд. філол. наук: 10.02.15. Київ, 2000. 17c.

8. Князева Г.Ю. Понятие ассимиляции заимствований и методика её исследования. Лингвисика и методика в высшей школе. 1990. Вып. 5. С. $128-131$.

9. Ковмир Т.П. Признаки включения заимствованных единиц в систему языка-реципиента. Семантика и прагматика языковых единиц. 1984. C. $10-13$.

10. Комарова К.О. Неасимільована французька лексика в сучасній англійській мові (на матеріалі британського та американського варіантів мови). Мовознавство. 1978. № 2. С. 61-66. 
11. Комлев В.И. Фонетическое, орфографическое и морфологическое освоение французских заимствований в немецком языке: дисс. ... канд. филол. наук: 10.02.15. Ленинград, 1072. 220с.

12. Коробова М.С. Ассимиляция немецких заимствований в английском языке. Учёные записки 1-го Московского пед. ин-та иностр. языков. 1967. T. 37. С. 173-188.

13. Коротких Ю.Г. Лексическое заимствование в современном немецком языке (на материале разговорной речи). Воронеж, 1980. 109с.

14. Крейн И.М. Французские заимствования 19 века в английском литературном языке. Іноземна філологія. 1965. Вип. 5. С. 45-49.

15. Крысин Л.П. Этапы освоения иноязычного слова. Русский язык в школе. 1991. № 2. С. 74-78.

16. Муромцев I.В. Особливості освоєння лексики іншомовного походження в сучасній українській мові (морфологічний аспект). Вісник Харківського ун-та. 1986. № 284. С. 72-77.

17. Пауль Г. Принципы истории языка (Под редакцией А.А. Холодовича). Москва, 1960. 500с.

18. Свечина И.Б. Ассимиляция англо-американских заимствований во французском языке. Иностранные языки в школе. 1982. № 3. С. 66-72.

19. Сорокина Л.Н. Ситуация, прогресс и результаты заимствования в лексике. Иностранные языки в школе. 1979. Вып. 14. С. 97-105.

20. Шахрай О.Б. К проблеме классификации заимствованной лексики. Вопросы языкознания. 1961. № 2. С. 53-58.

21. Штирбу Т.А. Лексико-семантические вопросы англо-русской двуязычной ситуации: автореф. дисс. ... канд. филол. наук: 10.02.15. Минск, 1977. 24c.

22. Filipovic R. Primary and secondary adaptation of loan-words. Wiener Slavistisches Jahrbuch. 1977. Bd. 23. S. 116-125. 